\title{
Pengembangan dan Implementasi Komunikasi Pendidikan Bencana Tsunami
}

\author{
Pratiwi Cristin Harnita \\ Fakultas IImu Sosial dan IImu Komunikasi, Universitas Kristen Satya Wacana, Salatiga, Indonesia \\ E-mail: pratiwi.harnita@uksw.edu
}

\begin{abstract}
Abstrak
Komunikasi dalam penanggulangan bencana tidak lepas dari penggunaan media baik dalam audio maupun visual. Dalam komunikasi media yang digunakan sebagai saluran penyampaian pesan disebut medium komunikasi. Penelitian ini bertujuan untuk mencari medium komunikasi pendidikan bencana yang paling efektif berdasarkan pendekatan kuantitatif deskriptif. Pengambilan sampel dalam penelitian ini berusia 7-20 tahun yang pernah mengikuti kegiatan sosialisasi kebencanaan oleh BMKG dengan metode survei kepada 175 anak muda di Kabupaten Cilacap. Dalam konteks komunikasi, medium menjadi penting karena merupakan saluran untuk penyampaian pesan. Fungsi komunikasi adalah penyampaian pesan untuk dapat dipahami bersama dengan tujuan memberi informasi, edukasi dan persuasi. Dalam upaya komunikasi pendidikan bencana oleh BMKG, ditemukan berbagai kegiatan yang telah dilaksanakan seperti Goes to School medium yang digunakan dalam penyampaian pesan berupa powerpoint, buku saku bencana, dan video animasi. Beberapa temuan terkait medium yang paling disukai oleh anak muda dalam komunikasi pendidikan bencana adalah sosialisasi (pertemuan tatap muka), film, iklan layanan masyarakat, dan roleplay. Sedangkan video animasi pembelajaran di kelas tidak begitu disukai.
\end{abstract}

Keywords: komunikasi pendidikan bencana, medium komunikasi, fungsi komunikasi

\section{Development and Implementation of Tsunami Disaster Education Communication}

\author{
Pratiwi Cristin Harnita \\ Fakultas IImu Sosial dan IImu Komunikasi, Universitas Kristen Satya Wacana, Salatiga, Indonesia \\ E-mail: pratiwi.harnita@uksw.edu
}

\begin{abstract}
Communication in disaster management uses a variety of media. In communication context, the media used as a channel for delivering messages that called the communication medium. This study aims to find the most effective disaster education communication based on a descriptive quantitative approach. Reserchers took samples aged 17-20 years old who had participated in disaster socialization activities that held by Meterorological, Climatological, and Geophysical Agency in Cilacap, Central Java, Indonesia and every respondent has had disaster experience. The number of research samples is 175 respondent. In the context of communication, the medium becomes important because it is a channel for delivering message. An import function of communication is how medium can delivered message to be undesrstood together. The fuction of communication is providing information, education and persuasion. It was found that varioys activities have beed carried out such as Goes To School, which is used to deliver messages used some communication medium like pocket books, animated video, and power point template. Fact findings related to the best communication medium were sozialization (face to face meetings), films, public service advertisements, and roleplays. Meanwhile, animated learning videos in class are not very popular.
\end{abstract}

Keywords: disaster education communication, communication medium, communication function 


\section{PENDAHULUAN}

Komunikasi resiko merupakan faktor yang penting dalam kebencanaan. Komunikasi resiko bencana membentuk persepsi tentang resiko dan memberikan pengaruh kepada tindakan yang ditunjukkan dengan kesiapsiagaan bencana dan tanggap bencana(Abunyewah et al., 2018). Hal ini akan mempengaruhi keputusan dalam manajemen tanggap bencana. Informasi tentang kebencanaan yang akurat dan terpercaya dilakukan pada saat sebelum ada bencana melanda. Kehadiran lembaga pemerintah seperti Badan Meteorologi, Klimatologi dan Geofisika (BMKG) menjadi sangat penting karena menjadi pusat informasi kebencanaan yang ada di Indonesia. Tugas lembaga inilah yang terus memantau kondisi alam dan perubahan iklim yang terjadi di langit Indonesia.

Indonesia merupakan Negara yang dikelilingi cincin api (ring of fire), sehingga bisa disimpulkan bahwa Indonesia rentan dengan bencana gempa, tanah longsor, banjir, dan lain sebagainya(Strunz et al., 2011). Tak hanya itu, fakta lain menyebutkan bahwa beberapa daerah di Indonesia juga rawan bencana Tsunami. Hasil studi literatur menunjukkan bahwa di pantai selatan Pulau Jawa menunjukkan wilayah yang beresiko terhadap tsunami karena ada petunjuk bahwa di wilayah tersebut pernah mengalami bencana tsunami yang sangat besar(Widiyantoro et al., 2020). Hasil analisis citra satelit Sentinel 2 A menunjukkan bahwa tataguna lahan dan kawasan di pesisir pantai selatan menunjukkan kerentanan tinggi terhadap gelombang tsunami. Hal ini dapat dilihat semakin luasnya lahan terbangun dan semakin sempitnya lahan yang bervegetasi. Pada sisi yang berbeda mengkomunikasikan resiko bencana pada masyarakat merupakan faktor yang sangat penitng dalam upaya mitigasi bencana tsunami. BMKG sebagai pemangku kepentingan melakukan sosialisasi dalam berbagai bentuk di antaranya adalah Sosialisasi Mitigasi Gempabumi dan Tsunami "BMKG Goes To School" di Kabupaten Cilacap. Agenda lainnya adalah penyelenggaraan Sekolah Lapang Geofisika yang diselenggarakan oleh BMKG Geofisika Banjarnegara. Komunikasi bencana dilakukan secara aktif sebagai upaya penciptaan kesiapsiagaan masyarakat terhadap bencana, membantu untuk meminimalisir korban, dan mempersiapkan lokasi yang aman sebagai tempat evakuasi.

Ada berbagai pendekatan komunikasi yang dapat dilakukan diantaranya adalah komunikasi secara top-down karena belum semua masyarakat mampu menilai resiko bencana di wilayahnya, karena keterbatasan akses pengetahuan, informasi, 
dan peralatan(Ifrcs, 2011). Media sosial merupakan media yang sangat umum digunakan untuk mengkomunikasikan resiko dan mitigasi berbagai bencana alam(Liu et al., 2020). Faktor yang harus menjadi pertimbangan adalah adanya fakta bahwa tidak semua masyarakat yang bertempat tinggal di wilayah dengan kerentanan tnggi bencana mampu mengakses dan menggunakan media sosial untuk berkomunikasi. Sehingga pemilihan medium menjadi penting, karena ada pertimbangan yang harus diambil seperti kondisi geografis, tingkat pendidikan, tingkat pendapatan. Pemahaman tentang siapa audiens (masyarakat) akan menentukan medium komunikasi yang tepat(Akeuchi, 2012).

Berdasarkan masalah pendistribusian informasi, maka dibutuhkan komunikasi dengan teknik persuasif dan medium yang tepat dalam penyampaian pesan kebencanaan melalui komunikasi pendidikan bencana. Komunikasi resiko akan berhasil bila ada pembelajaran tentang bencana yang holistik terfasilitasi dan terpercaya. Suatu masalah komunikasi bisa diketahui dari adanya kesenjangan pengetahuan dan pemahaman antara si pengirim pesan (komunikator) dan penerima pesan (receiver). Oleh karena itu komunikasi menjadi penting, melalui medium seperti booklet kebencanaan, iklan, film yang disiarkan melalui berbagai macam saluran komunikasi(Cheng et al., 2012). Namun, dalam proses komunikasi terjadi ketidaksepahaman atau kegagalan dalam memaknai pesan khususnya tentang kebencanaan.

Dilansir dari BBC News Asia menyebutkan bahwa ada masalah dalam komunikasi yang dilakukan oleh BMKG untuk membuat masyarakat menjadi lebih "sadar" dalam artikel yang berjudul "Indonesia Earthquake and Tsunami: How warning system failed the victims" (28 April 2018) dilaporkan bahwa terjadi masalah komunikasi antara lembaga pemerintah kepada masyarakat, selain itu saluran komunikasi yang menjadi tanda peringatan tidak berfungsi baik. "But there's a bigger problem-though the alert was sent out, and according to the communication ministry, repeated tsunami warnings were sent to residents via text message-they might not been received. A spokesmas for the disater agency sait the quake had brought down the area's power and communications lines and that there were no sirens along the coast-which might have rendered the alert essentially useless." Hal ini menunjukkan komunikasi kebencanaan masih perlu dikaji ulang. Memanfaat media massa dan media baru bisa menjadi jawaban.

Masyarakat secara langsung membutuhkan sebuah media komunikasi 
yang mampu menyalurkan partisipasinya. Dalam penelitian yang dilakukan sebelumnya, komunikasi untuk mitigasi bencana telah dilakukan dengan berbagai media massa. Dimana temuan yang didapat adalah kebutuhan informasi tidak dapat dipenuhi seluruhnya oleh media massa karena ada target keuntungan tertentu, dan masyarakat kemudian menyadari butuh saluran media baru untuk informasi kebencanaan yang lebih cepat (Lemona et al., 2020).

Selain pemanfaatan media massa dan media baru dalam komunikasi pendidiakn bencana. Program Goes to School menjadi salah satu program unggulan yang dilakukan rutin oleh BMKG di seluruh Indonesia. Pemerintah mencoba untuk menjalin komunikasi kebencanaan sejak dini dan masuk ke dalam institusi pendidikan(Amri et al., 2017). Anak-anak muda akan menjadi garda terdepan dalam proses penyelamatan(Bandrova et al., 2015). Kesadaran tentang kebencanaan menjadi penting agar dapat mengambil keputusan yang tepat ketika bencana terjadi. Komunikasi pendidikan bencana juga membentuk mentalitas calon-calon penyintas bencana.

Komunikasi pendidikan bencana penting dilakukan untuk meningkatkan kesadaran akan bencana dan keseriusan pemerintah dalam mempersiapkan segala kemungkinan ketika bencana itu terjadi(Amelia et al., 2019). Pernyataan dari penyintas ini menunjukkan bahwa adanya masalah komunikasi di mana masih banyak respon-respon yang menunjukkan bahwa adanya masyarakat yang belum siap menghadapi bencana. Menurut pakar Sosiologi perkotaan Universitas Indonesia, Linda Damarjanti yang dituliskan di kompas (9/10/2018) bahwa Indonesia belum memiliki "safety culture". Sehingga seharusnya pembangunan infrastruktur harus mempertimbangkan budaya aman.

Selain itu, budaya aman ini pun belum terinternalisasi pada alam berpikir masyarakat. Dalam situs kompas ini pun disampaikan tentang kasus bencana yang pernah terjadi seperti di Sulawesi Tengah yang pernah mengalami gempa bumi, tsunami dan likuefaksi. Padahal beberapa informasi dan penanda sebagai sarana komunikasi telah dipasang khususnya sebagai peringatan tsunami namun diabaikan. Apakah memang medium komunikasi yang digunakan tidak menarik perhatian, atau bahasa yang digunakan dalam penyampaian pesan tidak cukup menggugah kesadaran masyarakat? Oleh karena itu pemahaman tentang saluran komunikasi atau medium komunikasi yang digunakan sebagai upaya mengkomunikasi bencana perlu dianalisis lebih lanjut(Purworini et al., 2019). 
Perlu dicari medium /saluran komunikasi yang sesuai dengan budaya, tingkat pendidikan dan karakter masyarakat kita. Berbeda daerah dapat pula berbeda pendekatan. Apakah memang kegiatan rutin yang dilakukan dalam rangka komunikasi pendidikan bencana itu telah dapat meningkatkan kesadaran masyarakat khususnya anak muda?

Dalam penelitian ini, melihat bagaimana medium komunikasi yang sudah coba dimanfaatkan BMKG dalam melakukan pendekatan kepada anak-anak muda salah satunya melalui program Goes to School. Program ini dilakukan dengan aktif melakukan sosialisasi kepada anak sekolah.. Seluruh anak muda yang menajdi responden penelitian pernah mendapatkan sosialisasi pelatihan dari BMKG dan pernah mengalami bencana minimal $1 x$ dalam hidupnya serta masih memiliki ingatan yang jelas tentang sebelum dan sesudah bencana terjadi di daerahnya.

\section{METODE}

Penelitian ini memiliki tujuan untuk mencari medium komunikasi yang disukai oleh anak muda untuk komunikasi kebencanaan. Penelitian ini dilakukan dengan pendekatan kuantitatif deskriptif. Penggalian data menggunakan metode survei namun dilakukan secara online dengan menggunakan google form.
Penelitian ini termasuk pada statistik yang bersifat non parametric.

\section{Proses Penggalian Data}

Penelitian ini dilakukan di Kabupaten Cilacap yang merupakan salah satu kabupaten rawan bencana Tsunami. Penelitian ini mendukung penggalian akan fenomena sosial yang terjadi dan diperkuat oleh data statistik deskriptif. Sampel penelitian adalah anak muda yang berusia 17-20 tahun yang pernah mengalami bencana dan pernah mendapatkan sosialisasi dari BMKG. Penyebaran kuesioner dilakukan melalui online dan bekerjasama dengan beberapa sekolah tinggi yang ada di Kabupaten Cilacap periode 25-30 April 2021. Kuesioner disebarkan kepada 175 anak muda. Selain itu peneliti juga mendapatkan sumber informasi sekunder dari pemberitaan media massa, jurnal dan buku pendukung. Trianggulasi data dilakukan dengan melakukan validasi.

\section{HASIL DAN PEMBAHASAN}

\section{Persepsi Sebelum dan Sesudah Bencana}

Berdasarkan hasil olahan data statistik, peneliti menemukan beberapa temuan terkait pemikiran anak muda di kabupaten Cilacap yaitu sebagian besar responden telah memahami tentang apa yang harus dilakukan ketika bencana terjadi. Bencana 
yang terlah dialami terdiri dari berbagai macam sebagaimana pada Tabel 1.

Tabel 1. Berbagai bencana yang terjadi di wilayah studi

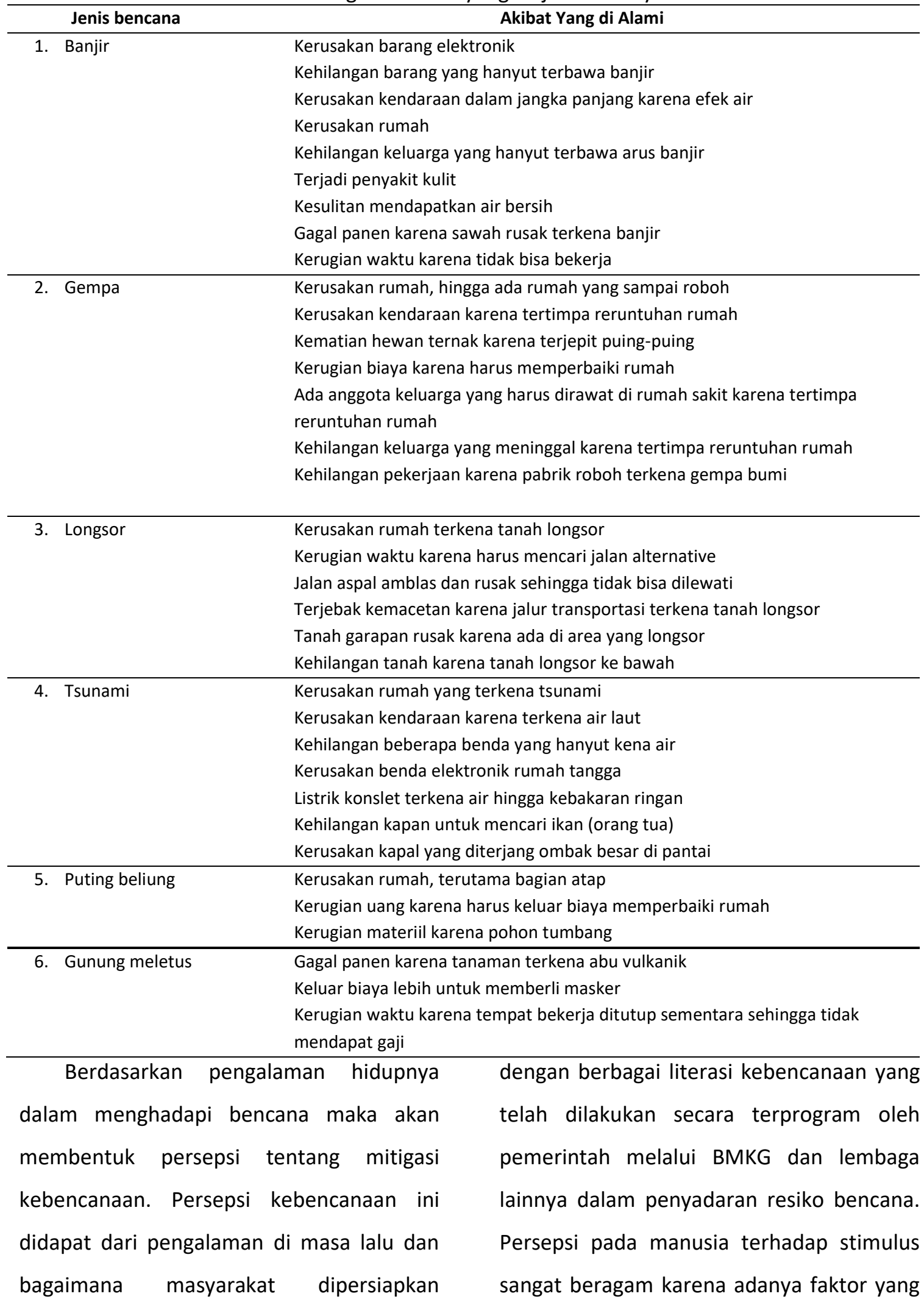


mempengaruhi persepsi tersebut. Secara umum persepsi memiliki tiga kriteria, yaitu adanya objek, indera atau reseptor. Faktor perhatian menjadi peran penting dalan proses persepsi (Qiong, 2017)(Martono et al., 2019). Perhatian para anak muda di Cilacap terhadap kejadian bencana menunjukkan bagaimana mereka dapat bertindak dan berperilaku pada saat bencana terjadi dan ketika bencana telah selesai. Persepsi dipengaruhi oleh faktor fungsional dan faktor strukural. Faktor fungsional adalah faktor yang berasal dari kebutuhan, pengalaman di masa lalu dan personal sedangkan faktor struktural merupan stimuli fisik dan efek saraf (Diniah, 2013). Persepsi yang muncul terkait mitigasi bencana mempengaruhi perilaku seseorang baik secara fungsional maupun secara struktural. Hasil analisis data yang menunjukkan persepsi baik fungsional dan struktural adalah sebagaimana disajikan pada gambar 1.

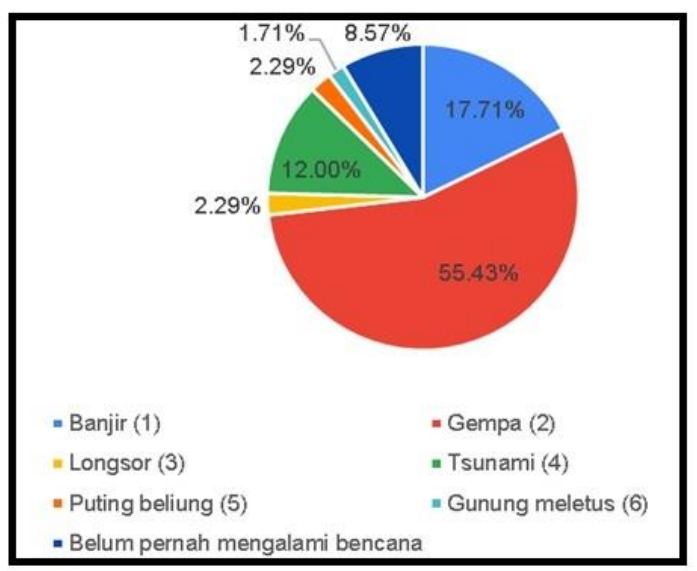

Gambar 1. Jenis bencana yang pernah terjadi
Jika dilihat dari persepsi dan perilaku yang sudah dilakukan oleh para responden dapat dikatakan bahwa mereka telah memahami apa yang harus dilakukan ketika bencana itu tiba(Tabel 2). Kampanye yang dilakukan oleh BMKG yang telah dilakukan secara terus menerus di wilayah bencana dan bekerjasama dengan institusi pendidikan memiliki pengaruh yang baik dimana sebagian besar responden mendapatkan pengetahuan terkait kebencaanan. Berdasarkan dengan data di bawah ini, sebagian besar (80\%) responden telah mendapatkan sosialisasi tentang pendidikan bencana yang dilakukan oleh BMKG di Sekolah (Gambar 2).

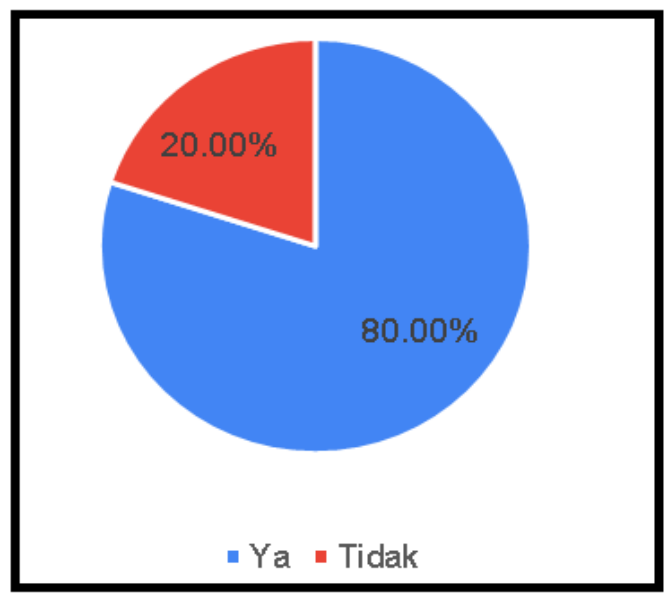

Gambar 2. Respon anak muda terkait keikutsertaan kegiatan sosialisasi kebencanaan oleh BMKG

\section{Medium Komunikasi Pendidikan Bencana Yang Paling Disukai}

Dalam ilmu komunikasi mengenal proses penyampaian pesan dalam konsep SMCR yang di kemukakan Berlo. Bila 
ditinjau dari proses penyampaian pesan

medium komunikasi dapat pula disebut saluran/channel/atau media. Dalam penyebaran informasi untuk meningkatkan kesadaran akan kebencanaan selain pemerintah membuat strategi seperti kampanye sosial dan event yang berkelanjutan, selalu tak bisa lepas dari saluran komunikasi yang dipakai. Seperti yang dilakukan dalam kegiatan BMKG Goes To School.

Tabel 2. Aktivitas yang dilakukan oleh repsonden Saat Bencana Terjadi

\begin{tabular}{|c|c|c|}
\hline $\begin{array}{l}\text { Jenis } \\
\text { Bencana }\end{array}$ & Saat Terjadi Bencana & Sesudah Terjadi Bencana \\
\hline 1. Banjir & $\begin{array}{l}\text { a. Menyelamatkan diri ke tempat yang lebih } \\
\text { tinggi dan aman } \\
\text { b. Menyelamatkan anggota keluarga yang } \\
\text { terjebak banjir dirumah } \\
\text { c. Mengamankan kendaraan dan barang-barang } \\
\text { elektronik } \\
\text { d. Mengamankan surat-surat berharga } \\
\text { e. Berusaha memadamkan listrik agar tidak ada } \\
\text { konsleting } \\
\text { f. Segera pergi ke tetangga yang rumahnya ada } \\
\text { g. Mentai dua nya } \\
\text { di tempat yang aman }\end{array}$ & $\begin{array}{l}\text { a. Mengungsi ke tempat yang aman } \\
\text { seperti balai pengungsian } \\
\text { b. Memastikan semua keluarga dalam } \\
\text { keadaan sehat } \\
\text { c. Memperbaiki barang elektronik yang } \\
\text { masih bisa diperbaiki } \\
\text { d. Menyimpan surat-surat berharga di } \\
\text { tempat yang lebih aman dan } \\
\text { membersihkan yang kotor } \\
\text { e. Memastikan jaringan listrik kering } \\
\text { f. Mencari tempat yang paling aman } \\
\text { untuk istirahat dan mencari } \\
\text { kemungkinan untuk kembali ke } \\
\text { rumah }\end{array}$ \\
\hline 2. Gempa & $\begin{array}{l}\text { a. Keluar dari rumah dan menjauhi pohon atau } \\
\text { bangunan yang tinggi } \\
\text { b. Mencari tahu apakah ada potensi tsunami } \\
\text { karena rumah dekat pantai } \\
\text { c. Mengamankan anggota keluarga yang ada di } \\
\text { dalam rumah } \\
\text { d. Menyelamatkan harta benda }\end{array}$ & $\begin{array}{l}\text { a. Mengecek keadaan rumah dan isinya } \\
\text { b. Mengamankan barang-barang yang } \\
\text { rawan hilang } \\
\text { c. Mengecek keselamatan anggota } \\
\text { keluarga } \\
\text { d. Melaporkan kejadian ke kelurahan } \\
\text { setempat }\end{array}$ \\
\hline 3. Longsor & $\begin{array}{l}\text { a. Menghubungi polsek agar ada pengaturan lalu } \\
\text { lintas } \\
\text { b. Melaporkan ke lurah setempat untuk } \\
\text { menolong korban } \\
\text { c. Menolong korban jiwa yang masih selamat } \\
\text { d. Mencari jalur alternative karena jalur biasa } \\
\text { terhalang longsoran } \\
\text { e. Menginformasikan adanya bencana kepada } \\
\text { keluarga agar keluarga tidak panik } \\
\text { f. Menyelamatkan benda-benda yang masih bisa } \\
\text { diselamatkan }\end{array}$ & $\begin{array}{l}\text { a. Mencari korban yang masih selamat } \\
\text { b. Mengamankan harta benda yang } \\
\text { selamat } \\
\text { c. Mengamankan lokasi dari penonton } \\
\text { bencana longsor } \\
\text { d. Menghubungi pihak terkait agar } \\
\text { bantuan segera datang }\end{array}$ \\
\hline 4. Tsunami & $\begin{array}{l}\text { a. Menjauhi pantai bersama keluarga } \\
\text { b. Mencari keluarga yang ada dirumah dan } \\
\text { segera mengajak mengungsi } \\
\text { c. Mencari informasi melalui internet } \\
\text { d. Mengamankan harta benda yang tersisa }\end{array}$ & $\begin{array}{l}\text { a. Mengecek keadaan tempat tinggal } \\
\text { dan lingkungan kampung } \\
\text { b. Melaporkan kepada petugas } \\
\text { kesehatan jika ada yang terluka }\end{array}$ \\
\hline $\begin{array}{l}\text { 5. Puting } \\
\text { beliung }\end{array}$ & $\begin{array}{l}\text { a. Segera masuk ke rumah dan mengunci semua } \\
\text { pintu dan jendela } \\
\text { b. Mengumpulkan anggota keluarga serumah } \\
\text { dan berlindung di rumah saja }\end{array}$ & $\begin{array}{l}\text { a. Mengecek kerusakan rumah } \\
\text { b. Memperbaiki rumah yang rusak } \\
\text { c. Gotong royong membantu tetangga } \\
\text { yang menjadi korban }\end{array}$ \\
\hline $\begin{array}{l}\text { 6. Gunung } \\
\text { meletus }\end{array}$ & $\begin{array}{l}\text { a. Menggunakan masker jika keluar rumah } \\
\text { b. Mengungsi jika diminta pemerintah karena } \\
\text { bahaya } \\
\text { c. Menggunakan pakaian tertutup dan masker } \\
\text { jika akan bekerja di luar rumah, terutama pada }\end{array}$ & $\begin{array}{l}\text { a. Membersihkan rumah } \\
\text { b. Menggunakan masker jika keluar } \\
\text { rumah }\end{array}$ \\
\hline
\end{tabular}




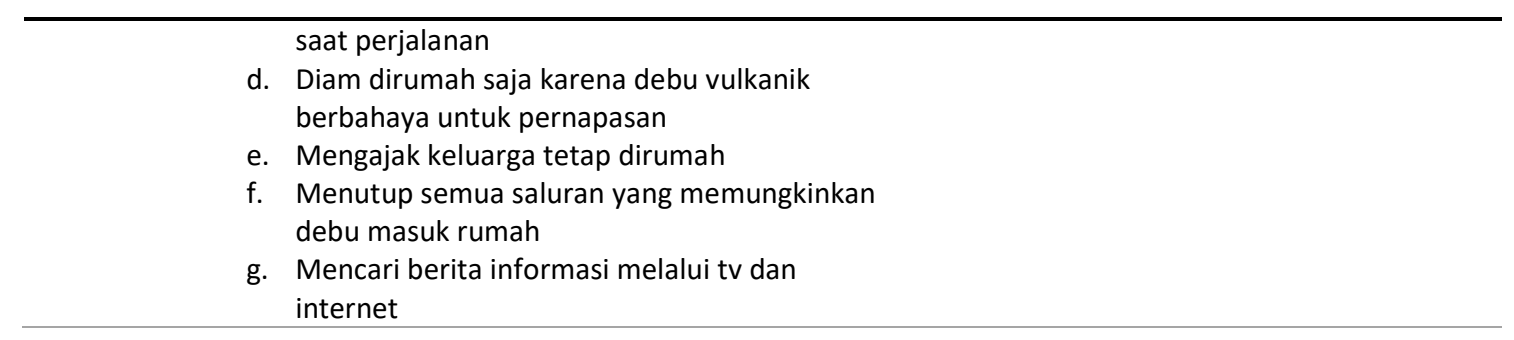

Dalam kegiatan ini BMKG yang berperan sebagai perpanjangan pemerintah melakukan fungsinya untuk menyadarkan dan mendidik siswa untuk mempersiapkan diri menghadapi bencana yang kapan saja bisa terjadi. BMKG juga memperkenalkan jenis-jenis bencana, dan membantu siswa mempersiapkan diri. Saluran komunikasi yang digunakan yaitu multimedia presentasi, buku saku bencana, animasi video pembelajaran(Fakhruradhi et al., 2019). Saluran komunikasi menjadi penting karena dengan bantuan saluran komunikasi maka akan memudahkan siswa (receiver) untuk memahami pesan yang ingin disampaikan oleh BMKG yang dalam konteks ilmu komunikasi disebut dengan sumber pesan (source).

Temuan yang menarik dalam penelitian ini adalah adanya kesenjangan antara model saluran komunikasi yang digunakan dengan saluran komunikasi yang disukai oleh siswa. Siswa adalah target khalayak yang diinginkan untuk bisa mengadopsi pesan terkait mitigasi bencana (Gambar 3).

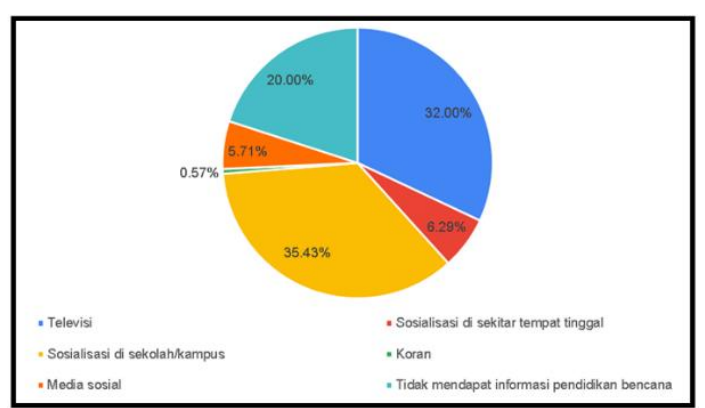

\section{Gambar 3. Sumber informasi}

Dalam penelitian ini menunjukkan bahwa sosialisasi yang selama ini dilakukan sudah tepat dan disukai sebagai upaya yang efektif untuk meningkatkan kesadaran akan kebencanaan, hal ini menunjukkan bahwa ruang kelas menjadi medium komunikasi yang tepat dimana komunikator yang menjadi sumber pesan dalam aktif berinteraksi dengan audiensnya. Namun demikian, ketika ditanyakan lebih mendalam, media mana yang cocok dan disukai anak muda dalam komunikasi pendidikan bencana adalah sebagaimana pada Tabel 3. 
Tabel 3. Jenis Komunikasi Pendidikan Yang Paling Disukai

\begin{tabular}{llr}
\hline \multicolumn{1}{c}{ Jawaban } & Jumlah & Persentase \\
\hline Sosialisasi langsung & 56 & $32.00 \%$ \\
Iklan layanan masyarakat & 30 & $17.14 \%$ \\
Animasi & 21 & $12.00 \%$ \\
Film & 33 & $18.86 \%$ \\
Roleplay mitigasi bencana & 23 & $13.14 \%$ \\
Video pembelajaran & 12 & $6.86 \%$ \\
\hline
\end{tabular}

Dalam kegiatan di dalam kelas, juga diberikan buku saku bencana sebagai alat penyampaian informasi. Dalam konteks komunikasi buku juga termasuk saluran pesan (channel) untuk penyampaian gagasan kedalam benak target audiens. Namun demikian buku saku kurnag begitu disukai. Bahkan sebagian besar sebanyak $53,71 \%$ tidak pernah membaca buku saku bencana (Gambar 4). Sejauh penelitian ini dilakukan, sosialisasi adalah cara pendekatan yang paling disukai. Pembelajaran mengenai kebencanaan dianggap paling efektif jiga langsung dilakukan dengan tatap muka. Siswa dapat langsung bertanya.

Biasanya dalam sosialisasi, seperti "BMKG Goes to School", siswa akan diajak untuk mengenal jenis bencana dan diajarkan bagaimana bisa bertahan dalam kondisi bencana. Di dalam kegiatan tersebut siswa diberi penjelasan oleh tim BMKG dengan menggunakan saluran komunikasi secara beragam. Dalam kondisi tertentu, dimana alat bantu tidak dimungkinkan, komunikator menjadi medium penyampaian pesan itu sendiri. Dalam artian tanpa menggunakan bantuan alat seperti powerpoint atau media lainnya, atau terkadang menggunakan power point, memutar video dan membagikan buku saku bencana. Namun demikian, upaya yang dilakukan dengan mempersiapkan berbagai saluran komunikasi di kelas ternyata memiliki beberapa kendala. Selain buku saku bencana yang hampir tidak pernah dibaca, video pembelajaran dalam bentuk animasi kurang begitu disukai. Ditunjukkan bahwa video pembelajaran menempati peringkat paling terakhir.

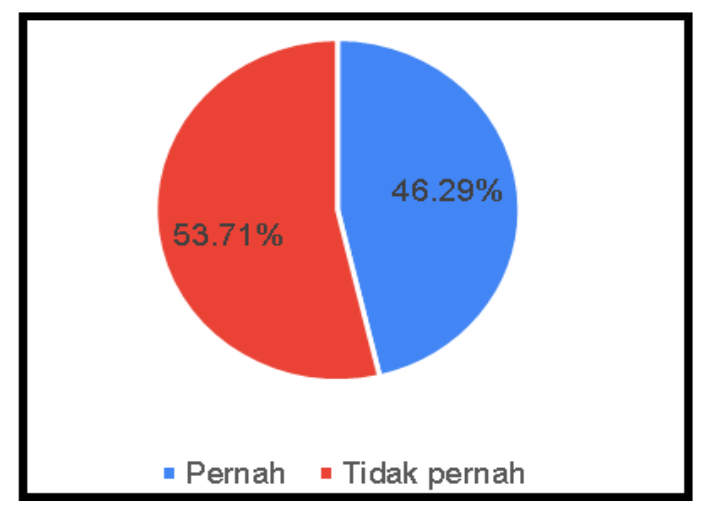

Gambar 4. Sumber informasi yang diperoleh dari buku kebencanaan. 
Berdasarkan temuan diatas perlu dipikirkan kembali mengenai saluran komunikasi mana yang paling efektif digunakan untuk meningkatkan kesadaran bencana. Studi kasus yang dilakukan pada 175 anak muda yang ada di Cilacap ini dapat menjadi gambaran sederhana bahwa pendekatan komunikasi yang dilakukan perlu juga memikirkan saluran komunikasi yang tepat.

Pemilihan medium komunikasi didasari dari pemahaman komunikator tentang target auidensnya. Dalam teori Elaboration Likelyhood Model (ELM), menunjukkan bahwa ada dua jalur berpikir target audiens. Memahami seperti apa target audiens membantuk untuk dapat berkomunikasi yang baik dengannya. ELM memberi asumsi bahwa tidak semua target audiens akan memproses informasi atau pesan. Hanya beberapa orang tertentu yang akan mengelaborasi pesan persuasif, dan sebagian lainnya lebih mengolah faktorfaktor yang berada di luar pesan. Terdapat dua jenis rute yaitu rute pusat (central route) dan rute pinggiran (peripheral route).

Dalam menentukan medium untuk komunikasi pendidikan bencana sebelumnya perlu memahami siapa target audiens yang akan dipengaruhi(Suryani \& Soedarso, 2019). Tipe central route adalah orang-orang yang memiliki daya pikir kritis, memerlukan banyak pertimbangan dalam mengambil keputusan. Sedangkan peripheral route lebih kepada orang-orang yang bersifat emosional. Biasanya orangorang di tipe ini mudah tergugah dengan hal-hal yang bersifat non logis. Berdasarkan hal ini, ketika menciptakan pesan tentang bencana maka perlu mempertimbangkan siapa yang ingin di sasar.

Ketika ingin menyasar orang-orang terdidik maka perlu diketahui ciri dari tenaga ahli (TA) yaitu orang-orang yang memiliki kemampuan literasi (baca tulis) yang baik, dan menyukai informasi. Dengan demikian, pesan yang dimunculkan akan menyesuaikan, yaitu dengan menambahkan banyak informasi terkait kebencanaan di dalamnya. Dalam teori ELM, pilihan rute kemudian berpengaruh pada pembentukan sikap seseorang. Ketika seseorang memiliki motivasi, kesempatan dan kemampuan dalam memproses pesan, maka mereka akan lebih kritis dalam memahami informasi atau pesan persuasi. Biasanya pada rute ini seseorang memiliki sikap yang lebih permanen (long endurance). Sedangkan, pada orang yang tidak memiliki sikap yang lebih permanen tersebut akan mudah dipersuasi dengan faktor-faktor bukan pesan yang akan mempengaruhi sikapnya yaitu orang yang pikirannya termasuk dalam rute pinggiran (pheripheral route)

Penerapan ELM pada rute pinggiran ini bisa dipraktikkan dengan menciptakan 
pesan yang sifatnya kengerian atau sebaliknya melalui pendekatan humor. Pada tipe target khalayak ini sangat dipengaruhi oleh hal-hal yang bersifat emosional. Faktor yang terdapat pada rute pinggiran adalah (1) Bukti sosial, (2) Keuntungan yang diperoleh, (3) Kelangkaan, (4) Kredibilitas, (5) Balas Budi dan (6) Otoritas. Dapat dicontohkan ketika terjadi gempa dan meletusnya gunung merapi, ketika warga sulit dipersuasi untuk evakuasi, maka pendekatan komunikasi melalui juru kunci kemudian menjadi efektif. Beberapa pendekatan lainnya dari jalur agama, misalnya memanfaatkan otoritas sebagai pemuka agama dan kredibilitas persuader dari pemuka agama setempat untuk menggerakkan warga.

Selain itu juga, mengetahui konteks budaya yang melatar belakangi dan pengalaman kebencanaan yang dimiliki perlu dipertimbangkan oleh pembuat pesan. Pada studi kasus 175 anak muda di Kabupaten Cilacap yang seluruhnya pernah mengalami bencana tentunya pesan komunikasi yang akan disampaikan tidak perlu umum seperti yang akan ditujukan kepada orang-orang yang belum pernah merasakan bencana. Maka memahami kebutuhan target audiens adalah hal yang mutlak. Setelah memahami siapa audiens yang disasar dan menentukan pesan komunikasi yang tepat, maka pemilihan medium komunikasi/saluran komunikasi juga tak kalah penting. Komunikasi pada umunya alah menyampaikan pesan. Maka dengan apa pesan itu disalurkan? maka butuh media komunikasi.

Terdapat dua pendekatan dalam melakukan eksposure pesan, jika ingin melakukan sesuai dengan konteks periklanan dan pemasaran. Pemerintah dalam hal ini BMKG dapat pula mengadopsi ilmu ini. Dalam periklanan terdapat mediamedia yang dapat dipakai tergantung dengan eksposure mana yang ingin dicapai. Jika ingin meningkatkan kesadaran masyarakat, dapat mengunakan media Above The Line (ATL) yaitu menggunakan media massa seperti televisi, radio, Koran. Sedangkan jika ingin lebih dekat kepada target audience menggunakan cara Below The Line (BTL) dimana biasanya jika pemasaran melakukan pameran, promosi terbatas, dalam konteks kebencanaan dapat dilakukan dengan melakukan sosialisasi secara langsung, pembagian flyer, dll. Pilihan medium komunikasi kini juga dimudahkan dengan menggunakan internet, sehingga muncul istilah Through The Line (TTI), dimana internet menawarkan eksposure pesan yang besar untuk meningkatkan kesadaran kebencanaan sekaligus membuat masyarakat dapat cepat berinteraksi. Penggunaan internet kemudian menjadi efektif ketika bencana 
terjadi, dimana masyarakat dapat melaporkan dirinya selamat dari bencana. Namun demikian, pemahaman akan media mana yang tepat menjadi penting, contohnya studi kasus 175 anak muda yang ada di kabupaten Cilacap, media massa yang menjadi sumber informasi pertama adalah televisi dan Koran, sedangkan sosial media tidak begitu besar. Untuk kedepannya dengan menanfaatkan berbagai lini media massa yang telah disesuaikan dengan karakteristik target audiens yang akan disasar menjadi penting. Cara berbicara kepada para warga pesisir yang tidak semuanya berpendidikan tentunya akan berbeda dengan para terpelajar. Begitu juga cara masyarakat ini bermedia, mungkin saja tak semua warga pesisir memiliki telepon genggam, sebagian besar mendengarkan radio dan televisi, tak semua dapat membaca menulis, sehingga medium apa yang paling tepat? maka radio dan televisi menjadi lebih tepat daripada menggunakan sosial media. Pemilihan medium pun akan berbeda dengan anakanak muda di perkotaan.

\section{Media Massa dan Fungsi Komunikasi}

\section{Dalam Meningkatkan Kesadaran Bencana}

Pada penelitian ini pun menggali dimanakan sumber informasi pertama terkait kebencanaan. Sebagian responden menyatakan sosialisasi di mayarakat dan sekolah, mengikuti kedua yang terbesar adalah televisi dan yang ketiga adalah koran. Televisi dan Koran merupakan salah satu media massa eksposure pesannya sangat kuat. Pada studi kasus di kota Cilacap, televisi dan Koran menjadi titik temu pertama kali tentain informasi bencana. Hal ini menunjukkan trend saluran komunikasi yang kini mengarah kepada digital tidak sepenuhnya berhasil dalam penyampaian informasi. Dalam penyebaran gagasan tentang kebencanaan, maka diperlukan komunikasi massa melalui saluran media massa. Komunikasi massa adalah komunikasi yang menggunakan media massa, baik cetak atau elektronik yang berbiaya mahal, yang dikelola oleh suatu lembaga atau orang yang dilembagakan, yang tujukan kepada sejumlah besar orang yang tersebar di banyak tempat, anonym dan heterogen (Mulyana, 2008 :83).

Media massa dalam konsep SMCR adalah medium atau saluran komunikasi (channel). Media massa sebagai saluran komunikasi massa memiliki berbagai fungsi, menurut Berdasarkan fungsinya media massa memiliki fungsi sebagai berikut:

Fungsi Informasi, Media massa adalah penyebar informasi bagi pembaca, pendengar atau pemirsanya. Berdasarkan hal ini, segala macam informasi terkait bencana baik upaya mempersiapkan 
masyarakat untuk tanggap bencana dan saat bencana terjadi disebarkan oleh media massa.

Fungsi Pendidikan, media massa adalah sumber ilmu. Dengan demikian tujuan menggunakan media massa untuk mendidik masyarakat terkait bencana dapat dilakukan. Tak hanya menyebarkan informasi saja, namun peran media massa dapat memberi edukasi kepada masyarakat untuk memahami tentang kebencanaan.

Fungsi Persuasi, Media massa adalah merupakan sumber komunikasi yang dapat mempengaruhi masyarakat untuk dapat sadar tentang kebencanaan. Media massa dapat menggerakkan seseorang untuk memberikan respon terhadap suatu kejadian. Berita dan kampanye sosial terkait kebencanaan memberikan pengaruh positif maupun negatif. Oleh karena itu media massa juga perlu mempertimbangkan bahwa tak hanya sekedar berita kebencanaan yag disampaikan, tetapi juga perlu memberi pengaruh yang menenagkan bagi masyarakat.

Jika melihat fungsi media televisi, Laswell (1975) dalam fungsinya terdapat (1) The surveliance of the environtment. Hal ini berarti media massa mempunyai fungsi sebagai pengamat lingkukan atau yang memeri informasi tentang hal yang erada diluar jangkauan penglihatan kepada masyarakat luas. Demikian pula tentang berbagai bencana yang muncul, kesadaran akan segala kemungkinan bencana dan dampak yang akan muncul sekitar lingkungan masyarakan perlu diingatkan. Hal yang menjadi kegelisahan dari BMKG, ketika menginformasikan tentang aplikasi Sirita dan area rawan bencana di kabupaten Kebumen dan Kabupaten Cilacap menyatakan bahwa adanya kemungkinan gempa dan tsunami yang waktunya belum bisa diprediksi. Padahal beberapa zona rawan bencana seperti yang ada di kedua kabupaten tersebut telah dipadati penduduk dan beberapa daerah tidak memiliki vegetasi yang mampu memberi pertahanan ketika tsunami itu terjadi.

Dengan adanya segala kemungkinan bencana ini, media massa seperti televisi dapat menjadi alat yang tepat dalam menyampaikan kondisi di lingkungan. (2) The correlation of the parts of society in responding to the environtment. Hal ini dapat diartikan bahwa media massa berdungsi melakukan seleksi, evaluasi dan interpretasi dar informasi. Dalam hal ini media dapat melakukan seleksi terhadap permberitaan kebencanaan. "Di Jepang media massa tidak memuat gambar korban, hal ini dimaksudkan agar menjaga ketenangan warga" ungkap Setyoajie selaku kepala BMKG Banjarnegara. Demikian pula seharunya media massa mampu memilah pemberitaan-pemberitaan terkait 
kebencanaan. (3) The Transmission of the social heritage from generation to the next. Hal ini dapat diartikan bahwa media massa sebagai sarana menyampaikan nilai dan warisan sosial bagi generasi selanjutnya. Khususnya dalam kebencanaan, di setiap daerah memiliki karakteristik budaya tertentu.

Seperti halnya di kebumen dan Cilacap, Jawa Tengah. Terdapat beberapa kearifan lokal terkait cara masyarakat membuat peringatan dini terhadap bencana, misalnya di setiap rumah ada 1 pohon. Pohon merupakan vegetasi yang rupanya dianggap menjadi tempat berlindung. Dengan memasang tangga ke atas pohon, menjadi perlindungan sementara jika tsunami terjadi. Selain itu juga terdapat alat peringatan dini sederhana yang di pasang di atas pohon seperti alat bampu yang dapat berbunyi ketika ada getaran yang cukup kuat atau angin yang keras. Melalui media massa dapat pula dibuat film dokmenter, atau pemberitaan softnews terkait hal itu. Maka daerah lain bisa belajar satu dengan yang lain.

\section{SIMPULAN DAN SARAN}

Berdasarkan hasil diskusi, maka dalam upaya meningkatkan kesadaran bencana, pemilihan medium komunikasi/saluran komunikasi yang tepat sangat diperlukan. Selain pemilihan medium, komunikator perlu memahami siapa target audiens yang ingin disasar. Komunikator perlu mempersiapkan isi pesan yang persuasif dengan beberapa pendekatan yang menarik sesuai dengan karakter audiens yang ingin disasar.

\section{UCAPAN TERIMA KASIH}

Ucapan terima kasih ditujukan kepada tim peneliti di Pusat Studi SIMITRO dan BMKG atas dukungannya dalam pelaksanaan penelitian ini sehingga dapat terlaksana dan dapat dipublikasikan pada jurnal nasional terakreditasi.

\section{DAFTAR REFERENSI}

Abunyewah, M., Gajendran, T., \& Maund, K. (2018). Conceptual Framework for Motivating Actions towards Disaster Preparedness Through Risk Communication. Procedia Engineering, 212(2017), 246-253. https://doi.org/10.1016/j.proeng.2018.01. 032

Akeuchi, Y. T. (2012). Utilization of Social Media in the East Japan Earthquake and Tsunami and its Effectiveness. 34(1), 3-18.

Amelia, L., Hayati, F., Milfayetti, S., \& Ichsan, I. (2019). Analysis of the Use of Kindergarten Watching Siaga Bencana Learning Model for Structured Positive Thinking Ability on Early Childhood. Budapest International Research and Critics Institute (BIRClJournal) : Humanities and Social Sciences, 2(3), 379-387. https://doi.org/10.33258/birci.v2i3.438

Amri, A., Bird, D. K., Ronan, K., Haynes, K., \& Towers, B. (2017). Disaster risk reduction education in Indonesia: Challenges and recommendations for scaling up. Natural Hazards and Earth System Sciences, 17(4), 595-612. https://doi.org/10.5194/nhess17-595-2017

Bandrova, T., Kouteva, M., Pashova, L., Savova, 
D., \& Marinova, S. (2015). Conceptual framework for educational disaster centre save the children life. International Archives of the Photogrammetry, Remote Sensing and Spatial Information Sciences ISPRS Archives, 40(3W3), 225-234. https://doi.org/10.5194/isprsarchives-XL3-W3-225-2015

Borthakur, S., Borthakur, A., \& Professor, A. (2015). Innovation in the Classroom Communication and the use of Performing Arts as a suitable alternative. IOSR Journal Of Humanities And Social Science Ver. I, 20(6), 36-39. https://doi.org/10.9790/0837-20613639

Cheng, Y. H., Cheng, J. T., \& Chen, D. J. (2012). The effect of multimedia computer assisted instruction and learning style on learning achievement. WSEAS Transactions on Information Science and Applications, 9(1), 24-35.

Diniah, S. N. (2013). Teachers' Perceptions towards the Use of English Textbook in EFL Classrooms (A Descriptive Study of EFL Teachers at One Islamic Senior High School in Cirebon). Journal of English and Education, 1(2), 72-81.

Fakhruradhi, Norma Susanti, R. M., Pratama, A., Fitri, R., Raudhiah, S., Zahrina, Rahman, A., \& Munadi, K. (2019). Media Engagement in Communicating Disaster Risk after the 2004 Indian Ocean Tsunami: A Perspective from Aceh. IOP Conference Series: Earth and Environmental Science, 273(1). https://doi.org/10.1088/17551315/273/1/012043

Hansson, S., Orru, K., Siibak, A., Asta, B., Krüger, M., Gabel, F., \& Morsut, C. (2020). International Journal of Disaster Risk Reduction Communication-related vulnerability to disasters: A heuristic framework.

51. https://doi.org/10.1016/j.ijdrr.2020.10193 1

Ifrcs. (2011). Public awareness and public education for disaster risk reduction : a guide. 102. https://doi.org/302200 E 06/2011

Kitchen, P. J., Kerr, G., Schultz, D. E., McColl, R., \& Pals, H. (2014). The elaboration likelihood model: Review, critique and research agenda. European Journal of Marketing, 48(11-12), 2033-2050. https://doi.org/10.1108/EJM-12-20110776
Lemona, M., Yunia, A., \& Pinariya, J. M. (2020). Komunikasi Mitigasi sebagai Langkah Strategis Pengurangan Risiko Bencana di Provinsi Banten. Warta ISKI, 3(02), 168177.

https://doi.org/10.25008/wartaiski.v3i02. 75

Liu, T., Zhang, H., \& Zhang, H. (2020). The impact of social media on risk communication of disasters - a comparative study based on sina weibo blogs related to tianjin explosion and typhoon pigeon. International Journal of Environmental Research and Public Health, 17(3), 1-17. https://doi.org/10.3390/ijerph17030883

Martono, M., Satino, S., Nursalam, N., Efendi, F., \& Bushy, A. (2019). Indonesian nurses' perception of disaster management preparedness. Chinese Journal of Traumatology - English Edition, 22(1), 4146.

https://doi.org/10.1016/j.cjtee.2018.09.00 2

Purworini, D., Purnamasari, D., \& Hartuti, D. P. (2019). Crisis communication in a natural disaster: A chaos theory approach. Jurnal Komunikasi: Malaysian Journal of Communication, 35(2), 35-48. https://doi.org/10.17576/JKMJC-20193502-03

Qiong, O. (2017). A Brief Introduction to Perception. Studies in Literature and Language, 15(4), 18-28. https://doi.org/10.3968/10055

Rahman, A., \& Munadi, K. (2019). Communicating Risk in Enhancing Disaster Preparedness: A Pragmatic Example of Disaster Risk Communication Approach from the Case of Smong Story. IOP Conference Series: Earth and Environmental Science, 273(1). https://doi.org/10.1088/17551315/273/1/012040

Strunz, G., Post, J., Zosseder, K., Wegscheider, S., Mück, M., Riedlinger, T., Mehl, H., Dech, S., Birkmann, J., Gebert, N., Harjono, H., Anwar, H. Z., Sumaryono, Khomarudin, R. M., \& Muhari, A. (2011). Tsunami risk assessment in Indonesia. Natural Hazards and Earth System Science, 11(1), 67-82. https://doi.org/10.5194/nhess-11-67-2011

Suryani, A., \& Soedarso, S. (2019). Language of Disaster and Society: The Socio-Emotional Functions of Language after Natural Disaster. 338(Prasasti), 34-40. 
https://doi.org/10.2991/prasasti-

19.2019 .5

Widiyantoro, S., Gunawan, E., Muhari, A., Rawlinson, N., Mori, J., Hanifa, N. R., Susilo, S., Supendi, P., Shiddiqi, H. A., Nugraha, A. D., \& Putra, H. E. (2020). Implications for megathrust earthquakes and tsunamis from seismic gaps south of Java Indonesia. Scientific Reports, 10(1), 111. https://doi.org/10.1038/s41598-02072142-z 